\title{
Non-radial symmetry of the transport system of Acropora corals
}

\author{
Nikolay N. Marfenin \\ Department of Invertebrate Zoology, Lomonosov Moscow State University, Russia \\ e-mail: nnmarf@mail.ru
}

\begin{abstract}
The branches of Acropora corals are formed by radially symmetric skeleton lined with soft tissue. However, the transport system does not conform to the same radial structure, but is bilaterally symmetric instead. The hydroplasm flows at constant velocity towards the apex (distally) along the upper side of the branch (facing the water surface) and towards the base of the branch (proximally) along its underside (facing the seabed). The axial and the largest canal do not play a major role in the transport of hydroplasm, however, if they do conduct any movement of fluid, it is directed proximally, i.e. towards the base of the branch. The results were obtained using the simple method of vital staining of broken off fragments of Acropora branches. Changing the position of the branch for a period of several weeks did not affect the pattern of hydroplasmic flow.

How to cite this article: Marfenin N.N. 2015. Non-radial symmetry of the transport system of Acropora corals // Invert. Zool. Vol.12. No.1. P.53-59.
\end{abstract}

KEY WORDS: transport system, Acropora, hydroplasm flows, radial bilateral symmetry, vital staining method.

\section{Нерадиальная распределительная система у кораллов рода Acropora}

\section{Н.Н. Марфенин}

Кафедра зоологии беспозвоночных Биологического факультета Московского государственного университета имени М.В.Ломоносова

e-mail:nnmarf@mail.ru

РЕЗЮМЕ: Ветви кораллов рода Acropora имеют радиально симметричный скелет, покрытый мягким телом. Однако распределительная система оказалась не радиально, а билатерально симметричной. Гидроплазма движется с равномерной скоростью по верхней стороне ветви (обращенной к поверхности воды) к ее верхушке (апексу), а по нижней стороне ветви (обращенной к дну) к основанию колонии (проксимально). Аксиальный кораллит и основной осевой канал не играют ведущей роли в перемещении гидроплазмы, которая обычно течет к основанию ветви. Обсуждаемые результаты были получены простым методом окрашивания скола ветви витальным красителем. Изменение положения ветви в течение нескольких недель не влияет на установившийся порядок течения гидроплазмы в ней.

Как цитировать эту статью: Marfenin N.N. 2015. Non-radial symmetry of the transport system of Acropora corals // Invert. Zool. Vol.12. No.1. P.53-59.

КЛЮЧЕВЫЕ СЛОВА: распределительная система, Acropora, течения гидроплазмы, радиальная, билатеральная симметрия, метод витального окрашивания. 


\section{Introduction}

As with all cnidarians, the corals' gastrovascular cavity plays the role of the transport system in which the flow of the hydroplasm (the fluid filling the gastric cavity) is enabled by the cilia of the endoderm (Gladfelter, 1983), although in Hydrozoa and Scyphozoa pulsations of the body also play an important role. The gastrovascular cavity is extensive and highly ramified in majority of colonial Cnidarians.

The skeletal morphology of Acropora branches is radially symmetrical (Fig.1-1), which is expressed in a fully consistent succession of skeletal elements and corresponding cavities between them in any radial direction away from the branch axis (Marfenin, 1983). The morphology of the branch consists of 5 subsystem cavities (Fig. 1-2B, 1-2D), namely:

- axial canal;

-s ubsystem of circumaxial cavities;

- radial cavities of corallites;

- subsystem of interradial cavities;

- subsystem of "surface cavities";

Morphologically transport system Acropo$r a$ represented by a set of cavities formed by the skeleton, with obvious signs of radial symmetry (Fig. 1-1;1-2). Therefore it is natural to assume that the transport system should also be consistent with radial symmetry. The purpose of this study was to test this hypothesis. How effective is this transport system? Is there any pattern to the movement of fluid through the labyrinth of canals of the gastrovascular system? These questions are particularly challenging for researchers of coral morphology. The non-transparent skeleton does not allow for direct observation of the direction and distance of hydroplasmic movement through the gastrovascular cavity inside a colony. Experiments with the use of injection methods provided very limited and circumstantial evidence about the morphology of the transport system as a whole. Literature on this subject is scarce (Gladfelter, 1983).

We attempted to discern a general pattern in the functioning of the transport system using a rather straightforward method(described below).

The study was conducted at the Great Barrier Reef in Australia in 1979. The results were never reported in full, save for a brief mention in a Russian-language paper on Acropora morphology (Marfenin, 1983).

\section{Materials and Methods}

The study was initially carried out on colonies of Acropora muricata (Linnaeus, 1758), first in the laboratory, then in natural conditions. In the laboratory the colonies were kept for less than 24 hours in flow-through aquaria with natural sea water. Five-centimeter segments used in laboratory experiments were broken off the coral branches immediately before the tests commenced.

Since coral regeneration is a very slow process, it takes several days for the open surface of a broken branch to seal over with tissue. While the inner cavities and the axial canal as the parts of the gastrovascular cavity are still exposed, the hydroplasm may leak out. In the natural environment, however, the 'wound' can be immediately sealed by excreted mucus.

The following describes a method for speed detection of functional units of the transport systems and the direction of hydroplasmic flow. A vital stain was applied in water at the exposed tip of a broken branch after mucus was rinsed off the surface (Fig. 2). We used Nile Blue Sulphate. The pipette was held as close as possible to the cross-section of the broken tip. The part of the surface through which the sea water is absorbed into the gastrovascular canals becomes saturated with stain within 5-10 seconds. When mucus is present, the stain has to be applied several times, with 1-minute intervals in between. Staining occurs in those pores and canals through which the stain is drawn into the colony with sea water. Those parts where no staining occurs correspond to areas of where hydroplasm is ejected through the exposed surface of the broken coral branch. To test the role of unstained sectors of the cross-section in the transport system the stain was also applied to the exposed surface at the opposite end of the branch fragment. If the hydroplasm really moves along longitudinal canals running through the fragments, then staining should be observed along one side of these fragments if the opposite side is unstained. If no staining occurs in a given part of a branch fragment at either end, it indicates the absence of hydroplasmic flow along this part of the branch. Vital stain is absorbed quickly by the coral tissue, especially since the transport system consists of a series of cavities, rather 


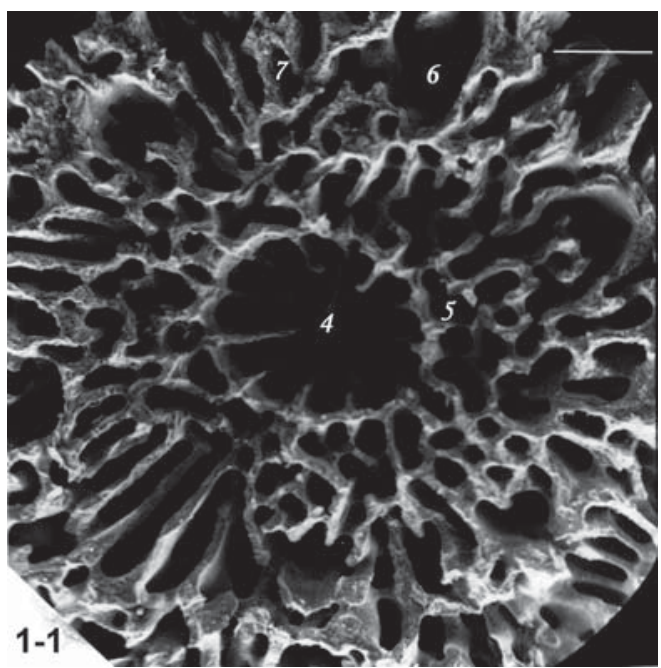

Fig. 1. Morphology of a single-stem colony of Acropora. 1-1 - cross-section of Acropora upper part of branch, SEM. 1-2 - schematic diagram of a single-stem colony of Acropora (from Marfenin, 1983): A - distal part of the branch, including the axial corallite; $\mathrm{B}-\mathrm{C}$ - skeleton structure and system of cavities in the longitudinal section, and D-E transverse section in the distal (B and D) and proximal ( $\mathrm{C}$ and $\mathrm{E}$ ) parts of a branch; $\mathrm{F}$ - base of the colony. Abbreviations: 1 - axial corallite; $2-1$ st order radial corallites forming on the costae of the axial corallite; $3-2$ nd order radial corallites; 4 - axial canal; 5 - subsystem of circumaxial cavities; 6 radial cavities of corallites; 7 - subsystem of interradial cavities; 8 - subsystem of "surface cavities"; 9 - encrusting zone. Scale bar $-0.5 \mathrm{~mm}$. Рис. 1. Схема строения ветви колонии Acropora (по: Марфенин, 1983). 1-1 - поперечное сечение в верхней части ветви Acropora (СЭМ, масштабная линейка 0,5 мм). 1-2 - схема строения колонии Acropora, состоящей из одной ветви (по Марфенин, 1983): А - дистальная часть ветви, включая аксиальный кораллит; В-C - строение скелета и система полостей в продольном сечении, D$\mathrm{E}$ - поперечные срезы в дистальной (B и $\mathrm{D})$ и проксимальной (С и Е) частях ветви; $\mathrm{F}$ - основание колонии. Обозначения: 1 - аксиальный кораллит; 2 - радиальные кораллиты 1-го порядка, которые формируются на костах аксиального кораллита; 3 - радиальные кораллиты 2 -го порядка; 4 - осевой канал; 5 - подсистема циркумаксиальных полостей; 6 - радиальные полости кораллитов; 7 - подсистема интеррадиальных полостей; 8 - подсистема «поверхностных полостей»; 9 - зона инкрустирующего роста.
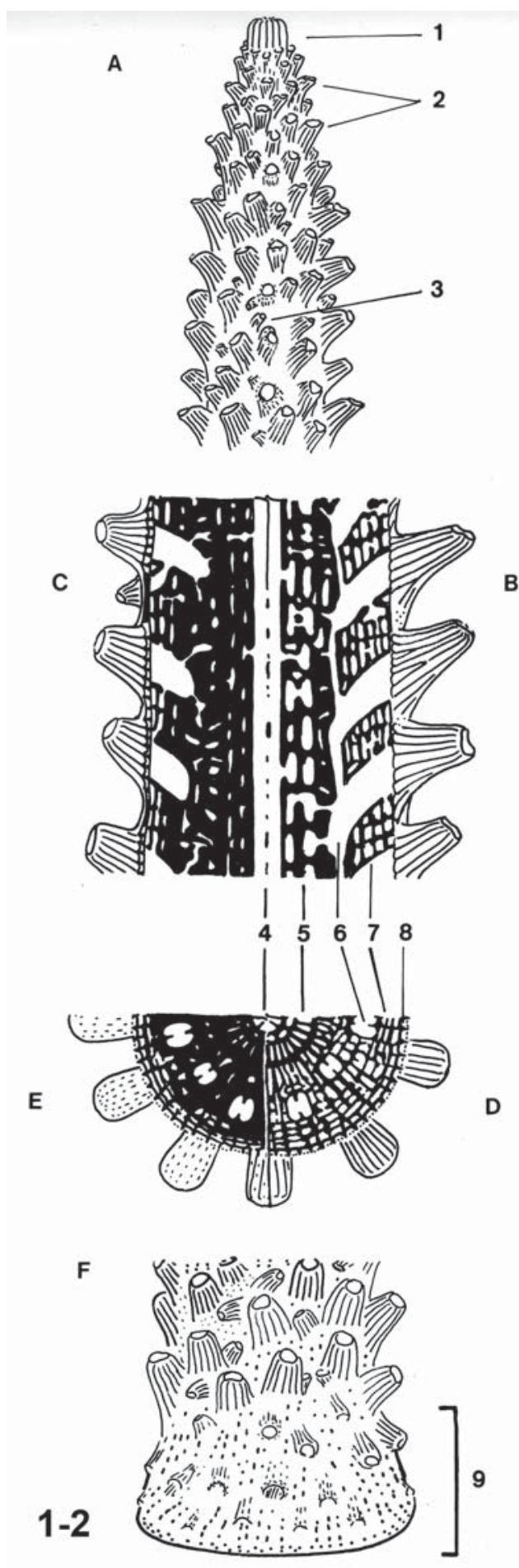

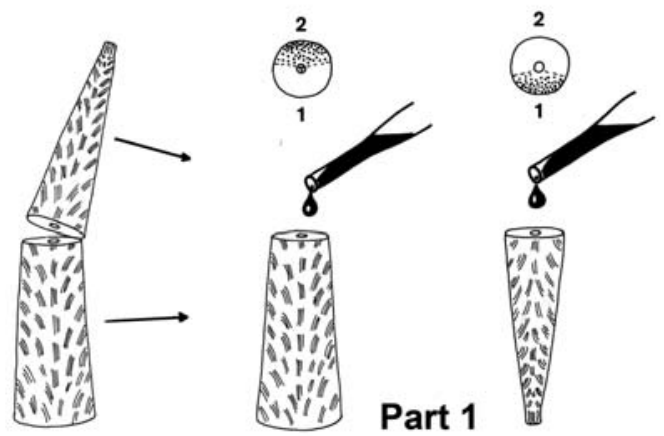

\section{Scheme and Result}

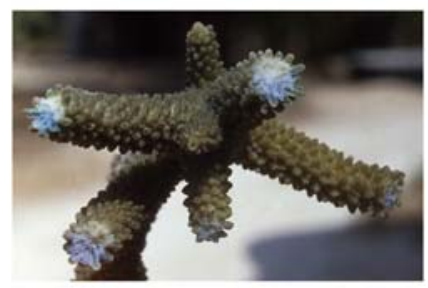

Part 2

Part 3

Fig. 2. Vital staining method for determining the direction of hydroplasmic flows in Acropora colony. Left: Schematic diagram of branch fragments and their cross-section surfaces stained with Nile Blue; 1 and $2-$ two lateral sides of Acropora branch; dotted (blue) - area of vital staining. Right: Photo of Acropora branches stained with Nile Blue.

Рис. 2. Метод витального окрашивания для определения направления токов гидроплазмы в колонии Acropora. Слева: Схематическое изображение куска ветви и ее поперечного скола, окрашенного Нильским красителем; 1 и 2 - две боковые стороны ветви акропоры; заштриховано (или голубым) область скола, окрашенная витальным красителем. Справа: фотография фрагмента акропоры, окрашенного нильским красителем.

than a canal with smooth walls. That is why vital staining can be used to mark the entrance region of the flow, but not its exit from the coral fragment.

The method can be applied in natural conditions. Just like in the laboratory, the stain is applied to the cross-section of a broken branch using a pipette. We used vital staining of branch fragments to study the following species in the sea: A. muricata (Linnaeus, 1758), A. cerealis (Dana, 1846), A. digitifera (Dana, 1846), A. millepora (Ehrenberg, 1834), A. nasuta (Dana, 1846), and A. pulchra (Brook, 1891).

The study was carried out at the Heron Island Research Station on the Great Barrier Reef. Permit to conduct the study and to collect the material was obtained from the Queensland Fisheries Service (No. 165, 19/07/1979).

\section{Results}

In all instances, i.e. both in the laboratory and in the sea, all of the studied species displayed the same pattern of staining in the broken branches. A sector of intensive staining usually covered $1 / 4$ of the surface (a quadrant). The least colored sector was also equal to about a quarter of a circle corresponding to the branch perimeter and was located on the opposite side of the axial canal of the branch. Judging by the location of stained and unstained sectors of the exposed cross-section, the hydroplasm flows distally (to the apex) along the upper surface of the branch (facing upwards, i.e. facing the water surface) and proximally (from the apex) along the underside of the branch (facing the seabed) (Fig. 2).

The central (axial) part of the branch does not absorb much of the stain. Near the apical tip of the branch (Fig. 1-2A) the movement of hydroplasm in the central canal is proximal, i.e. directed towards the base of the branch. The further from the apical tip, the wider the inactive axial area where no staining is observed, both on the distal and on the proximal side of the fragment.

Near the base of the branch (Fig. 1-2F) the axial part is strongly calcified, and the transport of hydroplasm is restricted to areas near the surface (Fig. 1-2C, 1-2E) but follows the same pattern, moving distally along the upper side of the branch, and proximally along the opposite side.

Hydroplasmic flow maintains the same direction as in branches in normal position when a large branch of $A$. muricata is turned upside down and left in the sea for several weeks on the same coral bush. 
Velocity of hydroplasmic flow can be determined by the speed of travel of stained water or suspended particulate matter carried therein. This includes the rate of exodus of zooxanthellae, which start leaving the coral tissue as their living conditions deteriorate. They also serve as markers of the sites where fluid is absorbed into the colony (Fig. 3). The flaggelar epithelium of the gastroderm continues to function and one can observe the flow of hydroplasm exiting the colony at constant velocity through the exposed surface of the damaged branch unprotected by a layer of mucus. No quantification of the rate of hydroplasmic flow was performed. However, what matters for the purpose of identifying the type of the transport system is that the transport of hydroplasm is unidirectional and continuous without noticeable changes in velocity.

\section{Discussion}

The functioning of the transport system in colonies of Acropora has so far been described in only one but very detailed paper (Gladfelter, 1983). The author injected a branch of a colony of $A$. cervicornis colony with fluorescent dye and observed the direction and rate of stain distribution under a luminescence microscope. The dye was injected via radial (lateral) corallites or via the axial corallite. After injection the dye moved in both directions: towards the base (proximally) and towards the tip (distally). However, in $77-100 \%$ of observations the rate of proximal flow beneath the surface of the branch was about 1.5 higher than the rate of distal flow. Fluid conduction in the axial canal was always unidirectional (proximal) and 2-3 times faster than the flow beneath the surface of the branch. The area between the axial corallite and peripheral canals running beneath the surface of the branch is barely involved in the transport of hydroplasm. The rate of hydroplasmic flows did not appear to be affected by lighting conditions. No significant differences were observed between the rate of flow beneath the surface of the branch at 3,7 and $10 \mathrm{~cm}$ from to the tip.

Unfortunately, over the past 30 years no new research has been reported on the functioning of the transport system in Acropora. Therefore it seems reasonable to compare my own findings with the paper in question, especially since they are not in full agreement.
The following common finding is of principal importance. It was discovered that the hydroplasm travels great distances commensurate with the extent of the branch in colonies of Acropora. As previously demonstrated in experiments with isotopic tracing, radiocarbonlabeled organic compounds and calcium can be carried over considerable distances inside the coral body, and the direction of their transport is toward the zones of maximum growth and calcification (Taylor, 1977).

Propulsion is induced by the flagellar beating of gastrodermal cells, which causes the evenly paced continuous flow of the hydroplasm. The flow is proximal in the canal of the axial corallite, and proximal or distal in the peripheral canals beneath to the surface of the branch.

Degree of calcification increases towards the base of the branch: the cavity of the axial corallite tends to become occluded and cavities between the axial corallite and the surface of the branch gradually dissipate (Marfenin, 1983).

Using a more straightforward method of applying vital stains to the cross-sections of broken branches, we managed to locate the systems responsible for the movement of hydroplasm, not only in the laboratory, but also in natural conditions. It was discovered that peripheral units do not play the same role in the transport of hydroplasm: the hydroplasm moves distally along the upward facing side of the branch, and proximally along the opposite side. Under these circumstances, the system of hydroplasmic transport seems to make sense. The flow of hydroplasm occurs in two opposite directions, which agrees with the notion of a rather closed transport system. Gladfelter's findings are not as easy to interpret. If the branches of Acropora are dominated by proximal movement of the hydroplasm, it would appear to be due to the sucking in of sea water by the colony. However, this leaves the question as to which parts of the colony are responsible for ejecting the water. According to my observations, the intact colonies of Acropora in either their contracted or expanded stationary state have no designated areas where the water exits the body of the colony.

It may be assumed that the difference in findings is due to the fact that in Gladfelder's experiments fluorescein injections did not target specific sides of the branch. In some tests the 


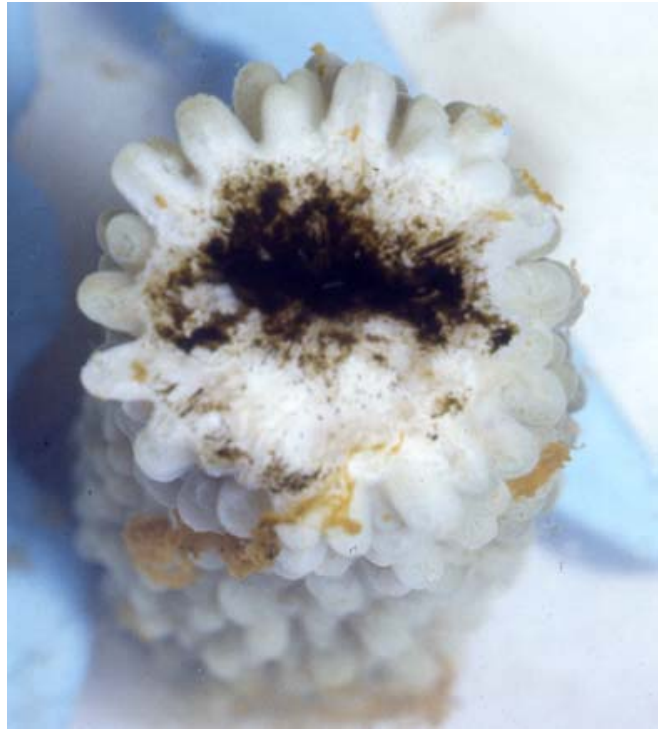

Fig. 3. Five-centimeter piece of Acropora branch after several hours of exposure in the laboratory in a cell with stagnant sea water. The dark area is marked by zooxanthellae deposited on the exposed surface. Рис. 3. Пятисантиметровый фрагмент акропоры после экспозиции в течении нескольких часов в лаборатории в сосуде с неподвижной морской водой. Темная область образована зооксантеллами, осевшими на поверхности скола.

dye was observed to move distally near the surface of the branch (14\% of observations in some samples). Considering that the distal flow of hydroplasm occurs in a section equal to a quarter of the branch perimeter, and given that injection sites were chosen at random, distal flows could be reported in only up to $25 \%$ of observations.

The method described in this paper allowed me to determine the spatial disposition of bidirectional hydroplasmic flows in a branch of Acropora. This is the main difference between findings reported here and Gladfelter's (1983) comprehensive account. Although it is difficult to study flow rates and other quantitative characteristics using this method. However, when it comes to the spatial orientation of hydroplasmic flows, it works better than the more sophisticated techniques described by Gladfelter.

In the proximal parts of the branch the pores are smaller due to ongoing calcification, as shown in Figure 1-2C, 1-2E. The anatomically pronounced radial symmetry would seem to suggest that the transport system is also radially symmetric, i.e. the hydroplasm flows in one direction along the axial canal and the surrounding subsystem of circumaxial canals, and in the opposite direction along the peripheral subsystems. There was no reason to assume a different pattern in the functioning of the transport system. However, tests based on injections of small particles of coal and carmine failed to either confirm or refute this assumption. The particles were easily captured by acontial filaments, which noticeably complicated attempts to trace their transport inside the colony (unpublished original findings).

Tests with vital staining of broken branches have demonstrated that the symmetry of the transport system is not radial, but bilateral. It means that future research, including studies that involve the use of fluorescent staining, has to take into account the asymmetry between different sides of the branch in terms of the rate and direction of hydroplasmic flow.

Since coloration consistently affects the same sectors of the exposed cross section of a coral branch, regardless of the location of the cleavage, it can be concluded that distribution of the regions of proximal and distal flows of hydroplasm is not linked to specific locations, but represents a general pattern characterizing the whole branch of Acropora.

Even-paced and unidirectional flow of hydroplasm has been described in colonies of some hydroids. In colonies of Ectopleura lar$y n x$ (Ellis et Solander, 1786) the coenosarc consists of two canals divided by a longitudinal septum (partition). This septum ends where the coenosarc becomes the body of the hydrant. The hydroplasm flows distally at constant velocity though one canal, then the flow of the fluid is reversed under the base of the hydrant and continues along the second canal in the proximal direction (Marfenin, 1985a).

Unidirectional flow of hydroplasm is continuous, without interruptions and changes in the rate of transfer of particles suspended in the fluid. When described using the proposed method, the movement of hydroplasm through the transport system of Acropora branches fully satisfies the above criteria.

Bidirectional gastrovascular flow has been described in the stolons of stoloniferan octocorals (Parrin et al., 2010). In most hydroids the 
transport of hydroplasm is not unidirectional; instead, it alternates its flow in opposite directions along the extended gastrovascular cavity (Crowell, 1957; Fulton, 1963; Hale, 1960; Wyttenbach, 1968; Harmata et al., 2013). In this type of transport system the flow of hydroplasm is induced by coordinated hydraulic pulsations of the coenosarc and hydrants (Marfenin, 1985b; Karlsen, Marfenin, 1984).

Therefore, it can be concluded that the transport system in Acropora is based on flagellainduced unidirectional propulsion of hydroplasm that is observed in some, though not all cnidarians. While branches of Acropora correspond to radial symmetry in the structure of the skeleton, the pattern of hydroplasm flows does not follow the basic skeletal radial symmetry.

\section{References}

Crowell S. 1957. Differential responses of growth zones to nutritive level, age and temperature in the colonial hydroid Campanularia // Journal of experimental Zoology. Vol.134. P.63-90.

Fulton C. 1963. The development of a hydroid colony // Developmental Biology. Vol.6. P.333-369.

Hale L.J. 1960. Contractility and hydroplasmic movements in the hydroid Clytia johnstoni // Quarterly Journal of Microscopical Science. Vol.101. P.339350 .

Gladfelter E.H. 1983. Circulation of fluids in the gastrovascular system of the reef coral Acropora cervicornis // Biological Bulletin. Vol.165. P.619-638.
Harmata K.L., Parrin A.P., Morrison P., Bross L.S., Blackstone N.W. 2013. Quantitative measures of gastrovascular flow in octocorals and hydroids: towards a comparative biology of transport systems in cnidarians // Invertebrate Biology. Vol.132. P.291-304.

Karlsen A.G., Marfenin N.N. 1984. [Hydroplasm movements in the colony of hydroids, Dynamena pumila L. and some other species taken as examples] // Zhurnal obsshey Biologii. Vol.45. P.670-680 [in Russian].

Marfenin N.N. 1983. [Colony morphology and transport system in two species of hermatypic coral genus Acropora] // Zoologichesky Zhurnal. Vol.62. P.5-13 [in Russian with English summary].

Marfenin N.N. 1985a. [The functioning of the pulsatoryperistaltic type transport system in colonial hydroids] // Zhurnal obsshey Biologii. Vol.46. P.153-164 [in Russian with English summary].

Marfenin N.N. 1985b. [Morphofunctional analysis of the organization of monopodial colonies of hydroids with terminally disposed zooids as illustrated by Tubularia larynx (Ell. et Sol.)] // Biological Bulletin of Academy of Science USSR. Vol.12. P.167-174 [in Russian with English summary].

Parrin A.P., Netherton S.E., Bross L.S., McFadden C.S., Blackstone N.W. 2010. Circulation of fluids in the gastrovascular system of a stoloniferan octocoral // Biological Bulletin. Vol.219. P.112-121.

Taylor D.L. 1977. Intra-colonial transport of organic compounds and calcium in some Atlantic reef corals // Proceedings, Third International Coral Reef Symposium. Vol.1. P.431-436.

Wyttenbach C.R. 1968. The dynamics of stolon elongation in the hydroid, Campanularia flexuosa // Journal of experimental Zoology. Vol.167. P.333-351.

Responsible editors: E.N. Temereva, K.G. Mikhailov 